Issue 1/2018

\title{
SELF-GOVERNMENT EMPLOYEE IN THE POLISH DEFENCE SYSTEM ON THE EXAMPLE OF MAZOWIECKIE PROVINCE
}

\author{
Jakub ADAMKIEWICZ ${ }^{1}$ \\ ${ }^{1}$ Vasil Levski National Military University, Veliko Tarnovo, Bulgaria \\ Email: elitsasd@abv.bg
}

\begin{abstract}
The subject of the article is an organization of local government authorities in the implementation of tasks related to security and defence. Attention is focused on issues of employment and organization of work. The issues addressed relate to the adequacy of employees' knowledge and experience within the limits of their professional duties, the adaptation of the number of employees to the purpose of the tasks and the public opinion on the activities of the security bureaus. The article is based on the results of the qualitative and quantitative studies carried out within the framework of the project "Local self-government in Polish non-military defence system" conducted by the Department of Security and Defence Systems from the Faculty of Logistics in Military, University of Technology, during 2015-2016, in Mazowieckie Province.
\end{abstract}

Keywords: local self-government; employee; defence system.

JEL Classification: $\mathrm{J}_{45}, \mathrm{H}_{12}$

\section{Introduction}

The foundation of state's stability and security is its defence system. One of the elements of that system is public administration, which has considerable meaning for its organizational and logistical stability. Civil workers are particular components of this "defence machine." Depending on the offered working conditions, they are effective in their professional actions or conduct their tasks incompetently. The aim of this article is to present work environment of those workers - responsible for security and defence affairs in local self-governments. The scope of the matter under investigation was limited to the main Polish units of administrative division (powiats 


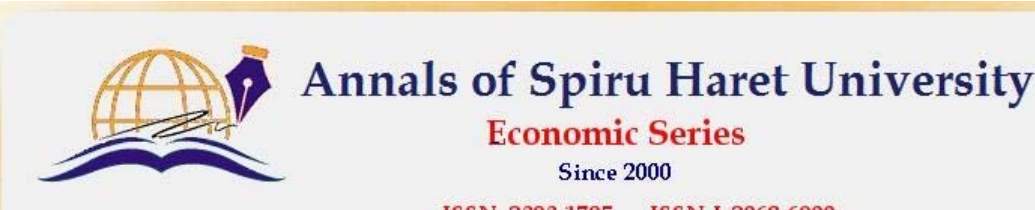

ISSN: 2393-1795 ISSN-L:2068-6900

\section{Issue 1/2018}

and gminas $^{l}$ ) in Mazowieckie Province, where the research was carried out. The investigation of the research problem was based on questions about the suitability of training and workshops offered to the current requirements and the recognition of their effort by managers, colleagues and the local community. Those conditions were treated as a motivation factors for work effectiveness.

Research, which was used for this article, was conducted within the project "Local self-government in Polish non-military defence system" carried out by the Department of Security and Defence Systems in Military, Faculty of Logistics, University of Technology. Survey was carried out with the use of quality and quantity methods. The first one consists of 11 interviews with civil workers responsible for defence affairs in regional councils and local governments in Mazovia region. Quality exploration was complemented with CAWI survey that aimed all of the 314 communities (gminas) in those regions. 79 replies were obtained, i.e. more than $25 \%$ of the examined population. All surveys were conducted between February and August 2016.

The purpose of the project described is the holistic familiarization with the organization of the defence system in local self-government. Moreover, valuable information for that publication could be found in obtained materials. Through the analysis, a work situation of civil workers that are responsible for our security can be shown. Even though it is impossible to present all the spectrum of barriers in their work environment, some of the major faults in management that have influence both on the professional engagement of workers and on the state of the organization of Poland's defence system were stressed.

\section{Local self-government in defence system in Poland}

According to Marian Kuliczkowski, defence system is "coordinating the inner collection of human, material and organizational elements that allow opposition to the threat of war depending on the aim and the purpose of the defence" [Kuliczkowski, 2016]. It consists of management and executive subsystems. The first joins the decisive and informational elements that appear in governmental structures. The second is composed of two sections - military units and non-military units composed of public administration structures, contractors

\footnotetext{
${ }^{1}$ Terms defining Polish main units of administrative division of self-governments do not have proper counterparts in English. Therefore, the Polish names - gminas and powiats - will be used in the article.
} 


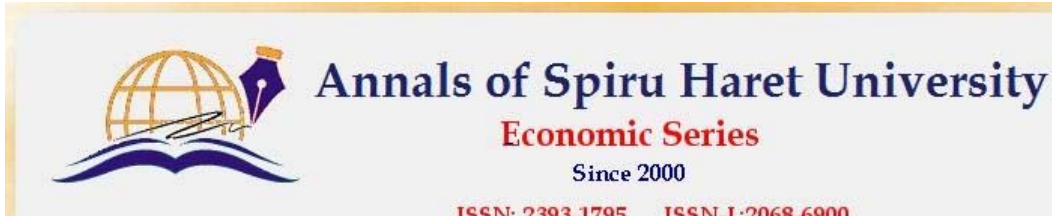

ISSN: 2393-1795 ISSN-L:2068-6900

Issue 1/2018

and other organizational entities. Polish defence Strategy document from 2009 depicts that state's defence system consists of all forces and measures destined for the realization of the defence tasks [Strategia obronności..., 2009].

A crucial non-military element in the defence system is public administration. Self-governments gain a special role within this system due to their proximity to citizens, who are responsible for most of the crucial tasks related to the implementation of the security strategy. Their defence activity is classified into three major categories. Firstly, they are accountable for protection of the population and state structures during a potential threat to the state's security, as well as during political-military crisis or war. Secondly, they provide informational and cultural base important for survival of humans that are endangered by various internal and external threats. Thirdly, they supply military forces with human resources and provide nonmilitary support for military activities all over the country [Kuliczkowski, 2013].

In practice, the activity in those three categories transfers to numerous procedures and formulas of administrative proceedings realized on various grades of organization and according to the three-level-division of the Polish territory. Within defence tasks, local administrations are responsible for registration of people for military record and performance of military qualification. They are also responsible for all the aspects related to the military service: the publication of information on mobilization and the duties of the citizens, the planning of personal and material performance during peace and war, and the issuing of administrative decisions in this regard. Moreover, self-government is responsible for the delivery of inductions to the army [Chrzyński, 2017]. Apart from defence activities, security administration on a local level administers affairs related to crisis management, public order and functioning of Civil Defence [Bonisławska, 2012]. Therefore, the scale of duties of this division of local self-government is remarkably wide.

Nevertheless, organizational divisions in public offices that are responsible for conducting those tasks are often lacking in personnel. The size of powiat's divisions liable for security affairs has usually two or even more work positions. In gminas, only one public servant works in such a department. Most of the time, the size of given division depends on financial resources and range of its administrative unit. Regardless of their work position, their duties are commonly transgressed with matters and tasks outside their field of work. Frequently, it concerns security of confidential information in public offices or matters relevant to organization of traffic and transport movement. According to the survey, only $13 \%$ of the workers in gminas had tasks connected only with security and defence. 

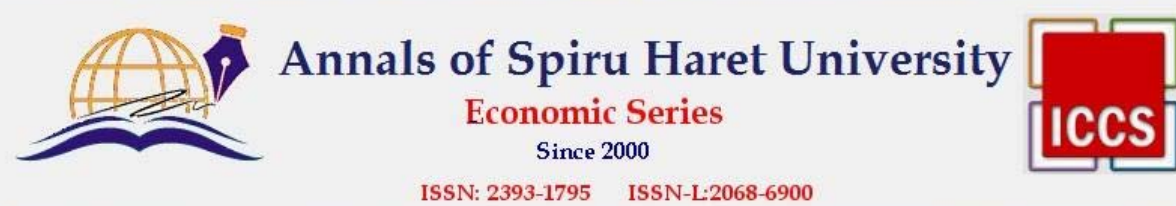

SSN: 2393-1795

ISSN-L:2068-6900

\section{Issue 1/2018}

Every third (34\%) worker had extended work duties. Matters related to defence and security are mainly only an addition to other work duties, as proved by more than a half $(53 \%)$ of the examined population. Such distribution of functions can be connected with the financial state of gminas or general lack of qualified specialists. However, it does not diminish concern and doubts that the qualifications of people who care for our security are not adequate to the wide spectrum of their tasks.

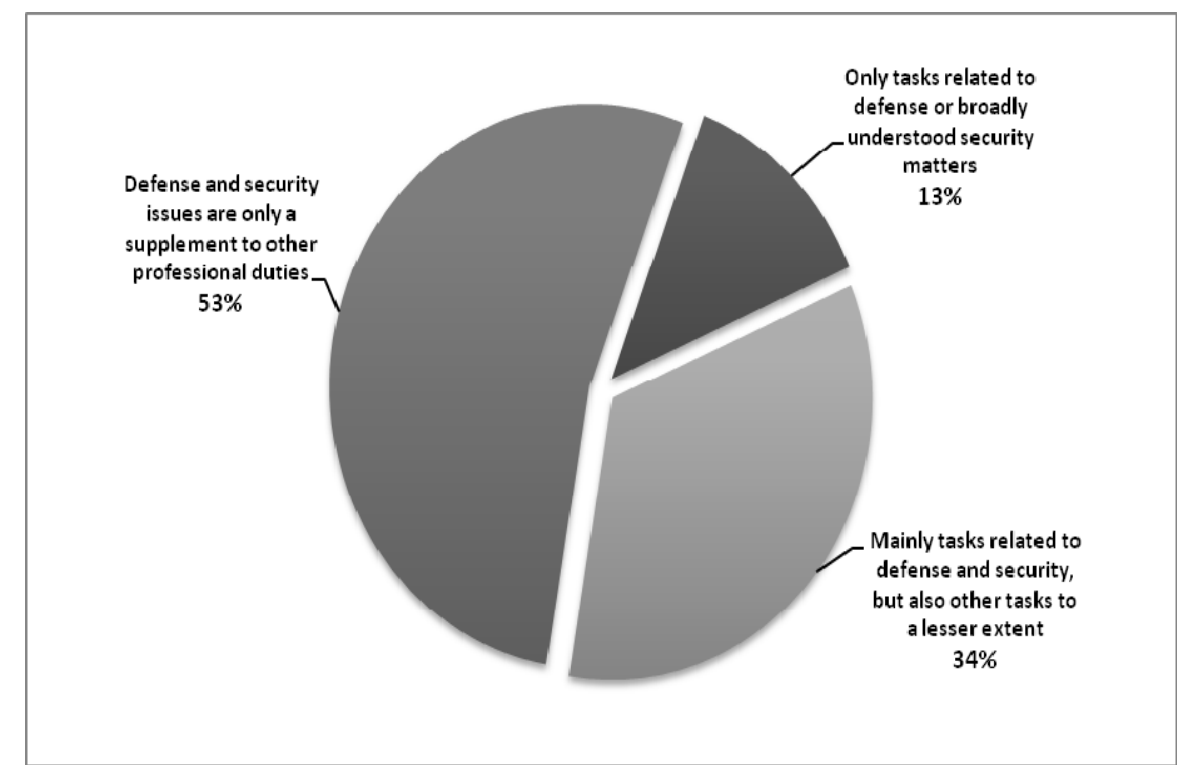

Figure no. 1. The scope of professional duties of officials responsible for defence in Mazovian gminas

Source: own research

\section{Work qualifications of officials in the Mazovian defence system}

In the face of the described problem, the concept of human capital as a factor defining the entire working class predisposition of the workers becomes more and more important. In "business" interpretation of that term is set of workers' attributes, which could be characterized by designated value and price [Shultz, 1961]. According to a different definition, human capital is a compilation of knowledge, education and individual traits, which enables effective realization of given tasks and goals [Bontis, 2003]. Work qualifications are demonstrated by work experience and education, etc. 


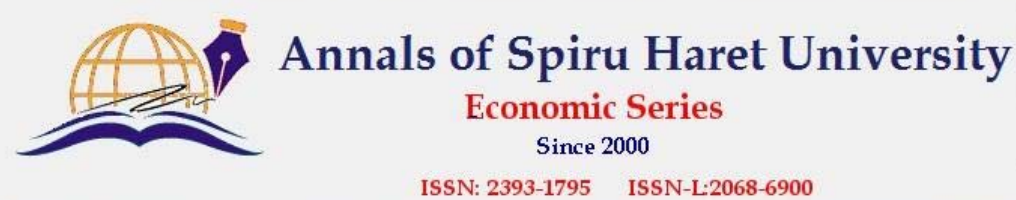

In the research, that was mentioned in the introduction, those factors were measured. Based on that, it was observed that the group of examined workers in local self-governments consists mainly of people with long work experience in administration. Most of the participants (around 85\%) have declared that they had worked as public servants for at least 5 years. Only $5 \%$ had worked on that position less than a year. Moreover, among the interviewees predominant were those with broad work experience in security affairs. More than $75 \%$ of the public servants worked at least 5 years on a position related to defence and security affairs. Only every fourth person had worked less than 5 years in security administration; among which only $8 \%$ had worked less than a year. More than $25 \%$ of the workers gained experience through the military service.
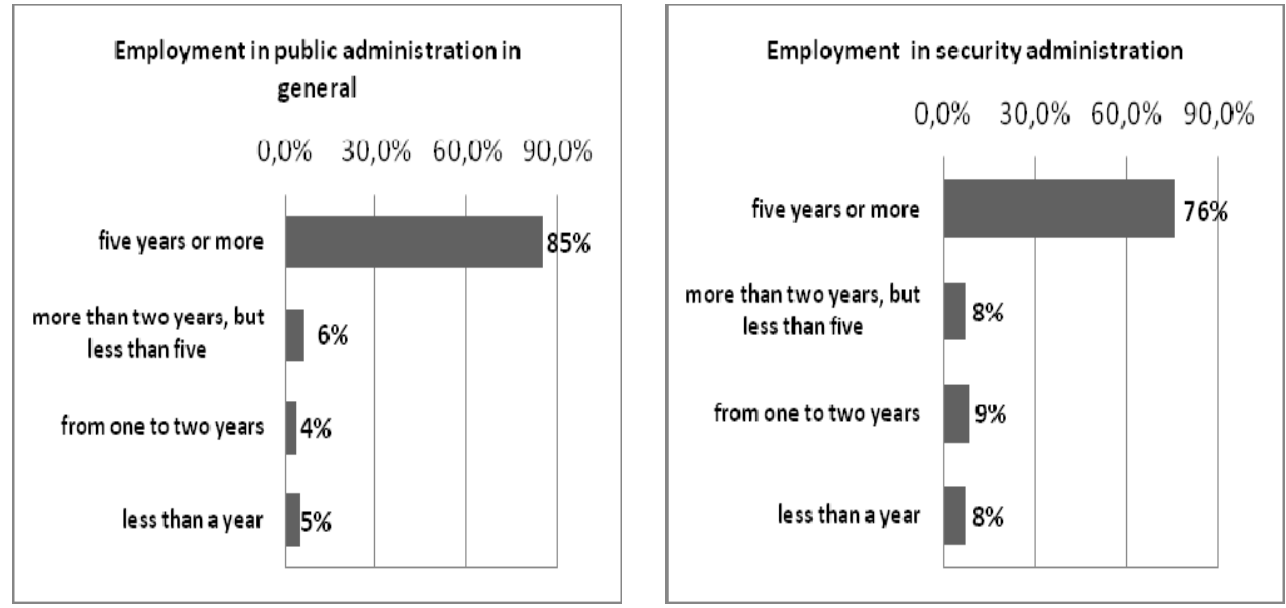

Figure no. 2. Period of employment for the participants in the study in the public administration in general (left) and in the security administration (right) Source: own research

Work experience does not always match an education background. More than $80 \%$ of the examined people had no education connected with security or defence. Slightly above $15 \%$ of the interviewees had postgraduate education in that field and $12 \%$ has additionally higher education related to that area of studies. In this situation, a quite numerous group had no academic base of theoretical knowledge about 

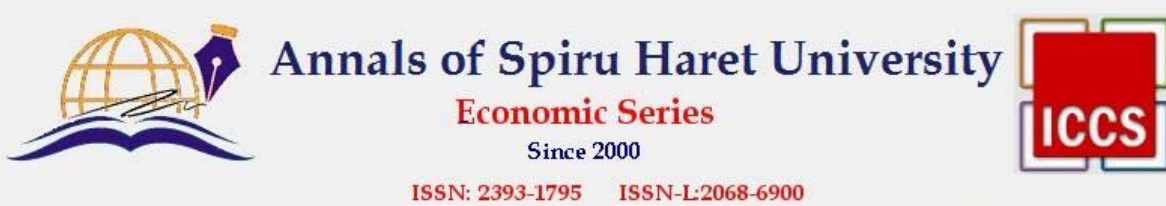

Issue 1/2018

security. It does not depict their lack of qualification, but shows an informational deficit, which can be complemented with other methods to broaden knowledge.

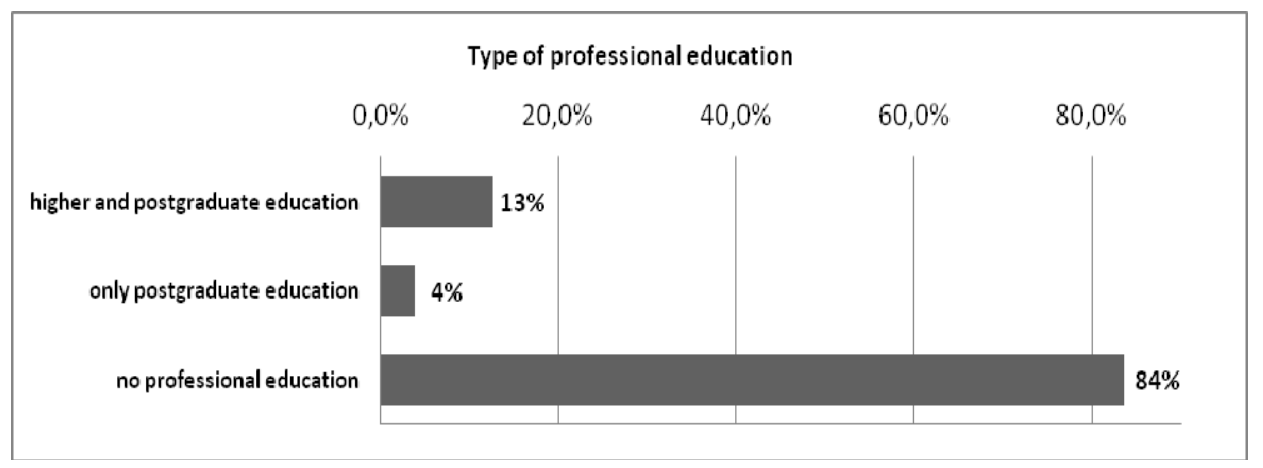

Figure no. 3. Type of professional education of the participants in the study Source: own research

The most common methods of enhancing qualifications related to security studies are trainings and workshops. They can be considered as various forms of education. Trainings have academic value. During lectures, workers can become acquainted with theoretical techniques of managing designated problems relevant to their work position. Workshops are a form of simulated situations connected with threats and circumstances, which the public worker could face during work. Due to crucial differences between various methods of education, the cost of its organization also differs. That is the reason why trainings, as a less expensive method, are chosen more often [Szmitkowski, 2017]. It can be shown in the research, where $91 \%$ of the civil workers in gminas had undergone a training during the 12 months before the research was conducted. More than $37 \%$ had have not participated in workshops simultaneously. The rest of the workers had participated in workshops once (less than $45 \%$ ), twice (about 10\%) or three and more times (11\%). 


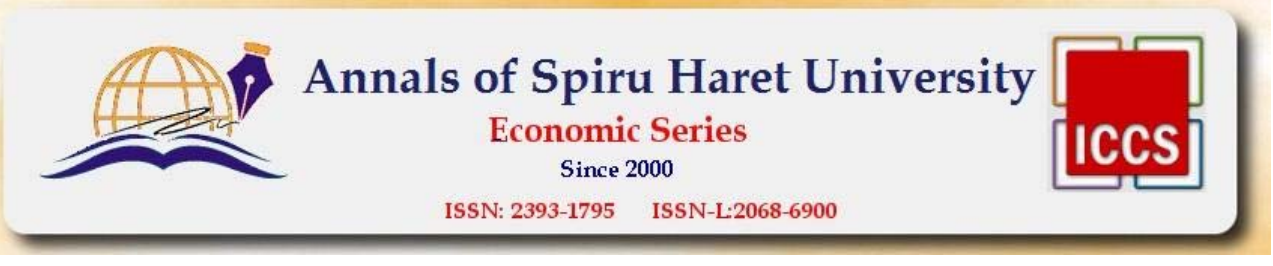

Issue 1/2018
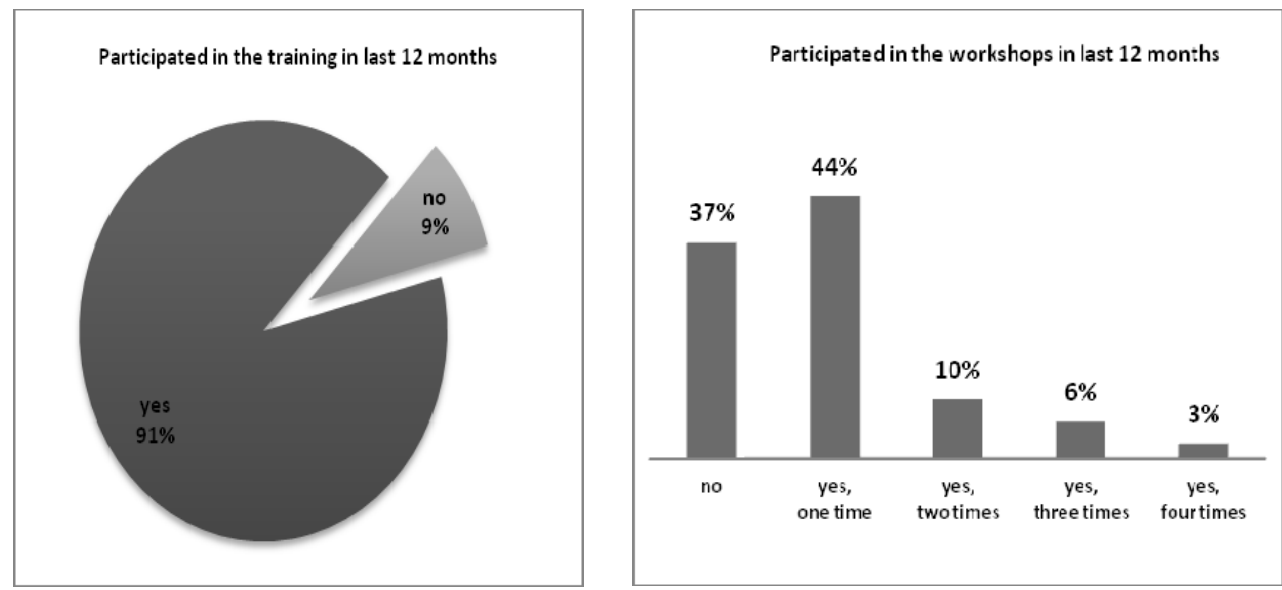

Figure no. 4. Participation in training (left) and workshops (right) of the participants in the study in the last 12 months to the moment of the survey

Source: own research

Wanting to concentrate on common forms of professional training, several characteristics of such educational services can be described. Trainings were mainly organized by Mazowiecki Urzad Wojewódzki ${ }^{2}$, as well as powiat offices, the Government Security Centre, Military Replenishment Councils and private training centres. The evaluation of the available offer was rather diverse, however criticism was dominating. As a fundamental objection to those trainings were their repetitiveness and monotonousness. Repetition of same topics, often not up-to-date with current challenges, were discovered. Lecturers were blamed for lack of creativity and reluctance to present solutions to more realistic problems. It was also suggested that the amount and duration of such trainings are not adequate to the extent of a given subject. However, it was noticed that in the past such undertakings, such as training, were conducted even once a month, instead of once a year. Finally, commercialization of similar projects was criticized - according to respondents, taking into consideration characteristics of work and the need of coaching, they should be costless (just like in the old times). Among the positive opinions, a variety of educational programs, which enables training offers to be wider, was appreciated.

\footnotetext{
${ }^{2}$ Mazowieckie Province Office.
} 


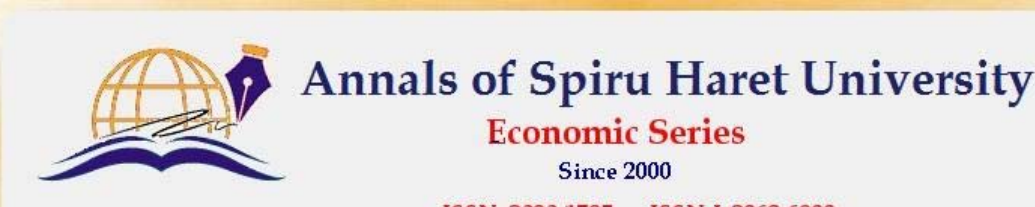

ISSN: 2393-1795 ISSN-L:2068-6900

Issue 1/2018

\section{Motivation factors in work environment}

Issues, such as education and work experience described above, are only one of the many factors, which have influence on the quality of offered services. Another crucial aspect that has impact on the professionalism at the office is effectiveness of all workers that transfers to the outcome of an institution they are working. In regards to the private company, which is profit-oriented, it is easy to estimate weather this undertaking is effective, because financial accomplishments and its rank on the market are considered as a prove for that. Showing appropriate factors for public sector is much more problematic, as not the positive financial result but the accomplishment of predefined goal/public good is a main motive of offices. It can be assumed that the performance of the tasks at the time and scale required demonstrates the effectiveness of the work of civil servants, which also requires the involvement and professionalism of the workers.

Capability of workers can be described by several components, for instance personal qualities, educational background, knowledge and motivation. Most of them develop during a process of environmental influence, including at the workplace. In materials related to human resources, consulting the main role of inspiring workers to increase the effectiveness of the whole office is emphasized. According to Beata Hysa and Bożena Grabowska, motivation is "essential and one of the major factors of work effectiveness increase" [Hysa \& Grabowska, 2014].

The concept of motivation has various definitions in the specialty literature. For example, Józef Penc states that motivation is a "group of factors of psychological or physiological nature that activates and organizes human behaviour, which aims at given goal" [Penc, 2011]. On the other hand, for Bolesław Kuc and Joanna Moczydłowksa motivation is a "psychological mechanism that activates and organizes human behaviour, which aims at given goal" [Kuc \& Moczydłowska, 2009]. What increases engagement of personnel is a proper motivational system [Kumari \& Pandey, 2011]. It is understood as a group of consistent and interrelated impetuses and conditionings aiming at encouraging workers to effort that would benefit both the worker and the office [Penc, 1996]. Components of that influence system consist of material and nonmaterial incentives. Anna Krzysztofek and Weronika Kumańska assign to the first group factors like trainings, social services, insurances and medical care. Organizational stimulus (ex. promotion, independence, access to information, flexible work hours etc.), psychological stimulation (praises and distinction, "good" team, positive unofficial relations, communication etc.) and technical stimulant (comfort and security, and standard of work) are considered to be 


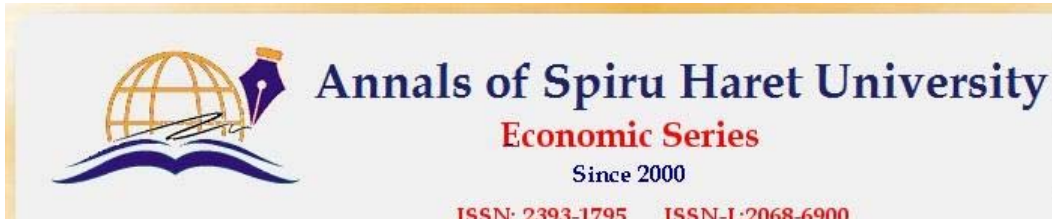

ISSN: 2393-1795 ISSN-L-2068-6900

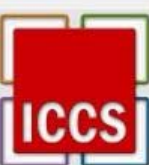

Issue 1/2018

nonmaterial ones [Krzysztofek \& Kumańska, 2003]. A particular and dominant aspect of motivation is financial incentive.

Other theories about work motivation depict a less detailed spectrum of stimulants and focus on general conditions of work environment. As an example, Herzberg's two-factor theory can be mentioned. In agreement with this, there are two groups of factors that have influence on motivation. The first one consists of stimulants that directly impact work satisfaction, ex. recognition, range of responsibility, promotion and potential for development. Hygiene aspects are components of the second one - they are salary, work conditions, relations between co-workers, company politics and management style. In such system, Herzberg's theory illustrates the first group as main stimulants to work engagement [Amstrong, 2005]. As sources of a true success in management, the most emphasized factors are recognition towards workers, assigning new responsible tasks and creating proper environment for development [Bochyńska-Śmigielska, 2012].

Based on similar discussions, Edward Deci, James Connel and Richrd Ryan have suggested that a particular role in inner motivation building plays appropriate leadership [Deci, Connell \& Ryan, 1989]. Bernard Bass and Bruce Avolio have supported their point of view and showed as an example soldiers whom, despite of stressful and unfavourable circumstances, have succeeded in their mission thanks to the right leadership [Bass \& Avolio, 2003]. Tove Hammer and H. Peter Dachler have emphasized that every action of the supervisor increases motivation of workers, while simultaneously increases probability of reaching a given aim [Hammer \& Dachler, 1975]. Those theories can be reflected in "empowerment" concepts, which are now gaining more and more appreciation in organizational psychology and which indicate the meaning of work environment in building workers' motivation. Rosabeth Kanter has differentiated various groups of factors supporting workers in realizations of the given tasks, such as non-formal (ex. social support) and formal authority, development opportunities (increasing of competences and gaining knowledge), supplies (essential to work performance, ex. financial), information and support (from co-workers and supervisors) [Kanter, 1989].

The ability to identify all of the motivation factors described above is the key to determine workers' predisposition to realization of assigned tasks related to security and defence. The appropriate space to develop work qualifications was already identified before. However, the element of social environment's influence over workers' effectiveness still demands more exploration. An estimation of the extent of respect towards public workers' effort from their supervisors, colleagues 

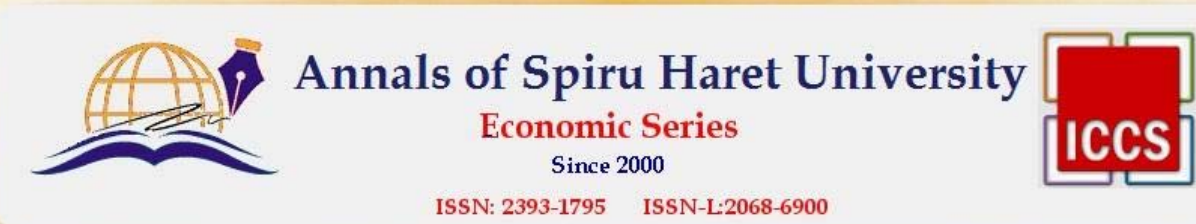

ISSN: 2393-1795 ISSN-L:2068-6900

\section{Issue 1/2018}

and local community is needed in order to analyze its influence on their state of mind and their willingness to realize work mission.

\section{Social perception of Mazovian defence system workers}

According to the conducted survey, workers responsible for defence issues on a gmina level feel rather appreciated by their supervisors. Most of the respondents (61\%) mentioned that defence and security issues are considered to be very or rather important by their supervisors. $16 \%$ of the participants shared different opinion, but only $2 \%$ admitted that their directors did not consider those issues as important at all. Simultaneously, every forth one (23\%) could not take any stance about that. Security and defence specialists are respected a bit less by their colleagues from different departments. Nevertheless, in that environment no marginalizing of security issues was noted as dominant. According to the survey, $30 \%$ of civil servants from defence departments noted that their colleagues treat defence and security issues as rather important and $6 \%$ as very important. On the other hand, every third person thought differently. $20 \%$ of the respondents observed that their co-workers think about defence affairs as rather meaningless and $8 \%$ as not meaningful at all. For the rest of the participants (36\%), it was difficult to say anything about that.
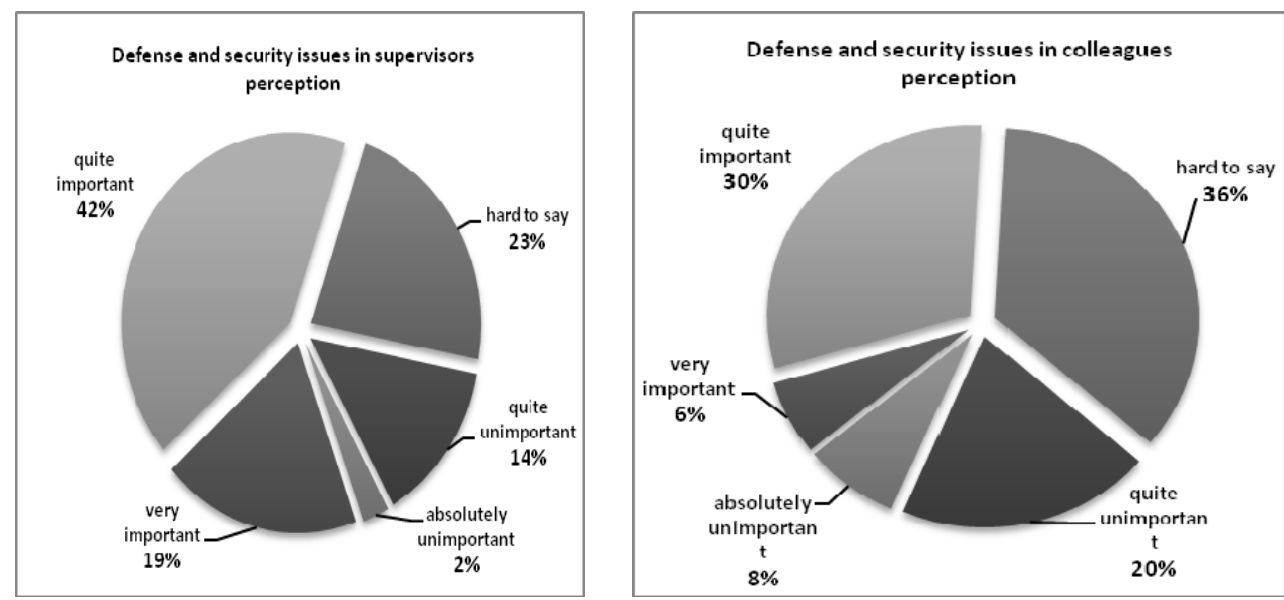

Figure no. 5. Perception of defence and security issues by supervisors (left) and colleagues from other departments (right) in the offices of the participants in the study Source: own research 

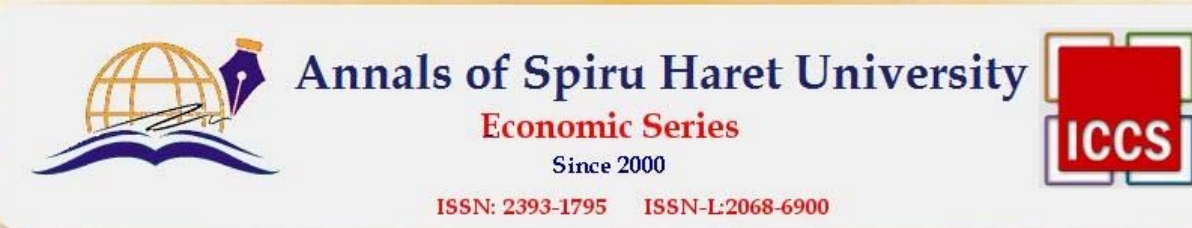

SSN: 2393-1795 ISSN-L-2068-6900

Issue 1/2018

The problem with cooperation between workers responsible for defence affairs and other employees was widened with additional emotional aspect. As stated in the survey, most of the respondents commented the general attitude of their colleagues towards defence issues positively as kindness (34\%), understanding $(20 \%)$ and even willingness to help (17\%). However, different feelings were also noted. Every fifth worker $(20 \%)$ noticed the lack of understanding from their co-workers. Additionally, 5\% of the participants described colleagues' attitude as antipathy and $4 \%$ as isolation. Such results depict rather worrying situation in a part of gminas, where matters related to security are not well-understood and even depreciated.

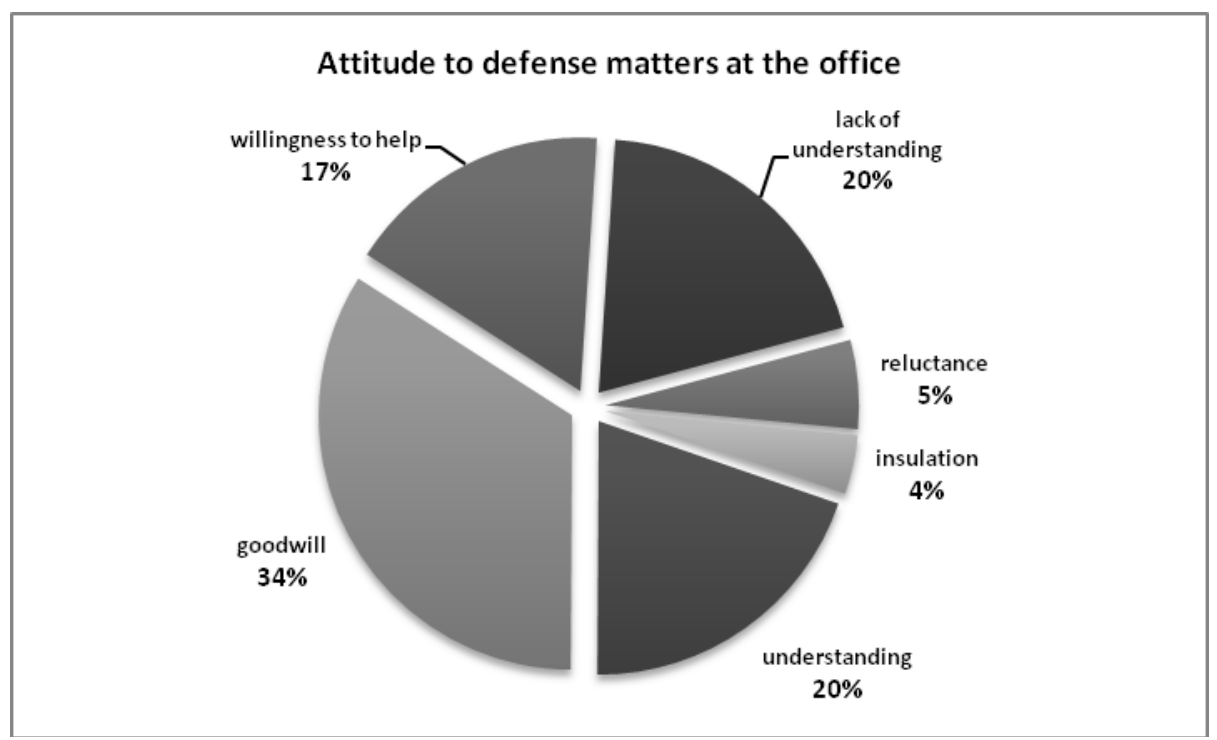

Figure no. 6. Words best describing the general attitude regarding the defence issues in the offices of the participants in the study

Source: own research

The scale of negation of defence civil servants' work can be seen in the reception by the local communities. That remark is a result from interviews with specialists, which represented powiats' self-governments. One respondent had mentioned that "some people are surprised that every powiat has an office which 


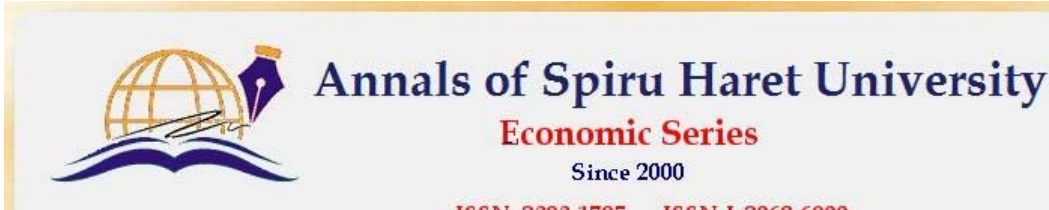

ISSN: 2393-1795 ISSN-L:2068-6900

\section{Issue 1/2018}

handles defence affairs - why should we have something like that?". Criticism and undermining of the purpose of departments liable for defence affairs have a negative influence on workers' morale. Another interviewee has mentioned "we hear comments that we have nothing to do and just have fun. It annoys us a little and even hamstrings us". The same person had also presumed that "The thing that must be changed the most is humans' mentality". According to him, only after that change, the defence system would function better.

\section{Conclusion}

The single official seems to have little importance in relation to the entire Polish defence system in its size and complexity. However, on the shoulders of each of them separately rests a duty and priority in responding to emerging risks symptoms, regardless to the hour and the time. This makes their job a service to the state and citizens, which requires the specific involvement of professional activity. Without proper motivation, this involvement would not be sufficient for defence and security tasks, which may lead to inappropriate actions in crisis situations.

We had to deal with this kind of lack of proper involvement during the disastrous storms in Polish Pomerania, in august 2017. Reaction to unexpected strength of local disaster occurred too late then. As a result, the scale of material losses was disproportionately large for this type of threat. However, it should be noted that the unfortunate intensifying of the dangerous weather phenomena occurred this time late Friday afternoon. This is the time when officials have customary finished their work and went home. Moreover, the absence of qualified staff was the main reason for over-long waiting for a proper reaction [Czubkowska, 2017]. So, in this particular situation, the human factor chiefly failed. Mostly because of an insufficient involvement which was due to daily routine and not going out of the specified framework of professional activity. The example of Pomeranian storms shows just how important clerks in a security system are and how well should they be prepared for the job.

Based on the research presented in this article, it is possible to formulate conclusions on the preparation of Mazovian security officials for the challenges they face in their professional work. Firstly, there is a shortage of experts educated in this particular field of knowledge. Nevertheless, the educational offer in the security specialization, based mainly on theoretical vocational training, seems to be insufficient. Secondly, there is sometimes no adequate emotive support for defence workers in their work environment. Although employers (most often the political authorities of local governments) understand the significance of professional work on 188 


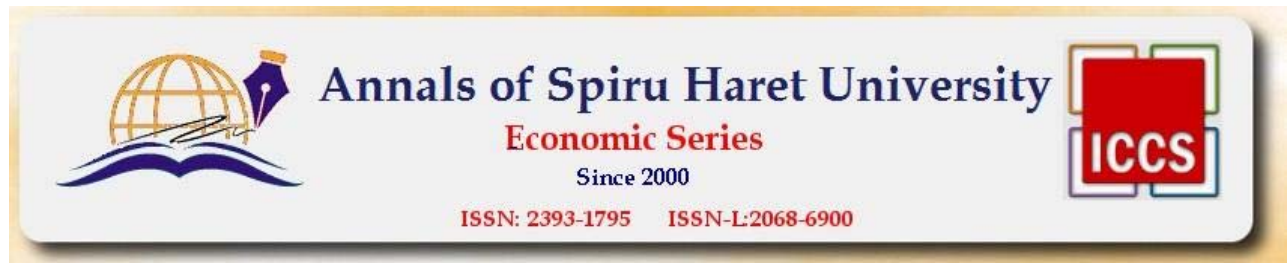

Issue 1/2018

military and security matters, the rest of the social scene seems to be less convinced to spend public funds for similar purposes. This applies in particular to the local population, for which security those regional agencies and workplaces are created. This attitude of the society can be particularly frustrating for officials who often derive and function in these social structures. However, the Mazovian selfgovernment departments responsible for security and defence issues seem to work properly according to the presented research. Despite the many challenges that arise in this region each year, it still manages to maintain a relatively stable and secure situation conducive to local socio-economic development.

\section{References}

Amstrong M., Zarzadzanie zasobami ludzkimi (Kraków: Oficyna Ekonomiczna, 2005).

Bass B. M. \& Avolio B. J., "Predicting Unit Performance by Assessing Transactional and Transformational Leadership," Journal of Applied Psychology, No. 2 (2003).

Bochyńska-Śmigielska E., "Determinanty zaangażowania i efektywności zawodowej," Zeszyty naukowe Towarzystwa Doktorantów UJ, no. 4 (2012).

Bonisławska B., "Zadania administracji samorządowej w zakresie bezpieczeństwa lokalnego," Zeszyty Naukowe WSEI, seria: Administracja, no. 2 (2012).

Bontis N., "National Intellectual Capital Index, the Benchmarking of Arab Countries," Journal of Intellectual Capital, vol. 5 (2003).

Chrzyński R., Zadania obronne $w$ systemie planowania $i$ finansowania samorzadu terytorialnego, [in:] Samorzad terytorialny $w$ systemie obronnym Rzeczypospolitej Polskiej, Z. Trejnis, J. Adamkiewicz (ed.), Wydawnictwo Adam Marszałek, Toruń (2017).

Czubkowska S., Państwo daje sobie radę od poniedziatku do piatku. W godzinach pracy urzędów, „Dziennik.pl”, 2017, http://wiadomosci.dziennik.pl/wydarzenia/artykuly/ 557000,polska-otwarte-od-8-do-16-nawalanica-osttrzezenie-godziny-pracy.html

Deci E. L., Connell J. P. \& Ryan R. M., "Self-Determination in Work Organization," Journal of Applied Psychology, no. 74 (1989).

Hammer T. H. \& Dachler H. P., "A test of Some Assumptions Underlying the Path Goal Model of Supervision - Some Suggested Conceptual Modifications," Organizational Behavior and Human Performance, no. 14 (1975).

Hysa B. \& Grabowska B., "System motywacji pracowników administracji publicznej na podstawie wybranej jednostki ZUS," Zeszyty Naukowe Politechniki Ślaskiej, no 74 (2014).

Kanter R. M., "The New Management Work,” Harvard Business Review, no. 66 (1989).

Krzysztofek A. \& Kumańska W., Wplyw motywowania pracowników na efektywność pracy w przedsiębiorstwie. Studia i materialy (Miscellanea Oeconomicae, Kielce, 2003). 


\section{Issue 1/2018}

Kuc B. R. \& Moczydłowska J. M., Zachowania organizacyjne (Difin, Warszawa, 2009).

Kuliczkowski M., Pozamilitarne przygotowania obronne $w$ Polsce. Uwarunkowania formalnoprawne, dylematy pojęciowe i próba systematyzacji (Wydawnictwo AON, Warszawa, 2013).

Kuliczkowski M., Pozamilitarne przygotowania obronne w Polsce. Próba systematyzacji procesowych oraz funkcjonalnych aspektów przygotowań (Wydawnictwo AON, Warszawa, 2016).

Kumari G. \& Pandey K. M., "Job satisfaction in Public Sector and Private Sector: A Comparison," International Journal of Innovation, Management and Technology, no. 3 (2011).

Penc J., Motywowanie w zarządzaniu (Wydawnictwo Profesjonalnej Szkoły Biznesu, Kraków, 1996).

Penc J., Kreowanie zachowań organizacji (Agencja Wydawnicza Placet, Warszawa, 2011).

Shultz T. W., "Investment in human capital," American Economic Review, vol. 5 (1961).

Strategia obronności Rzeczypospolitej Polskiej. Strategia sektorowa do Strategii Bezpieczeństwa Narodowego Rzeczypospolitej Polskiej (Ministerstwo Obrony Narodowej, Warszawa, 2009).

Szmitkowski P., "Szkolenia obronne w administracji publicznej jako istotny element edukacji dla bezpieczeństwa w RP," Zeszyty Naukowe Wyższej Szkoły Humanitas. Pedagogika, no. 15 (2017). 